good : twenty years later he became professor of natural history and planned and carried out the Challenger expedition. Another great oceanographer, Sir John Murray, continues the list of Edinburgh medicals who left without completing their degrees, a list which W. S. Bruce, who led the Scottish National Antarctic expedition, continues into the present century. Here is a record which will inspire the Edinburgh graduates of to-day, secure in the knowledge that they have got their degrees, to even greater achievements. As medical men they will do well to preserve in their minds Prof. Ritchie's reminder that there are Dark Continents of disease and suffering in all grades of modern society. The discovery, investigation and removal of these is especially the job of the modern medical man.

\section{Mathematics as a Compulsory Examination Subject}

Mr. D. BrownurE, who is an organic chemist and chemical engineer, has published a pamphlet strongly advocating the abolition of compulsory mathematics in university matriculation examinations, even for degrees in engineering or science. He claims that "the very great majority of candidates, say about 90-95 per cent, have no particular aptitude in the subject of mathematics, which is almost universally detested. . . . Actually, mathematical proficiency above the normal is no indication of superior intelligence. . . . It would, in fact, not be difficult to make out quite a good case for the contention that in a considerable proportion of cases proficiency in mathematics is actually a sign of mental deficiency. ... My experience with Euclid or geometry, or whatever it is now termed, had the natural result, as in the case of most other students, of regarding it as a pest to be learned by heart and forgotten completely as soon as the Matriculation examination was over." At a time like the present, when the educational system of Great Britain is being reconstructed, there is a place for a careful inquiry into the validity of the claims for the traditional subjects and methods of instruction. The use of wild and exaggerated language is not helpful in such an inquiry. A more useful step is the attempt, now being made by a committee representing all English School Certificate examining bodies and also the Mathematical Association, to provide an alternative course of mathematics, more closely allied to its applications, which can be followed by those who find the present school mathematics too abstract.

\section{Refugees in Great Britain}

Poltmical and Economic Planning (P E P) in a recent broadsheet (No. 216, January 14, 1944) gives a useful review of the present position of refugees in Britain and of the changes which have taken place during the War and since the appearance of Sir J. H. Simpson's report "The Refuge Problem" in 1939. The present number of civilian refugees is estimated at 139,430, including 50,000 Germans and Austrians, and 20,000 Allied seamen, a total which differs from that of the Prime Minister's statement of April 7, 1943 , in allowing for those who have left or died since the beginning of the War. Considerable progress has been made in utilizing the services of aliens with special professional, technical or academic experience. According to the Minister of Labour's statement of September 23, 1943, shortly after the 1941 registration $82 \cdot 5$ per cent of the men and 60 per cent of the women were in employment, and since 1941 the opportunities open to aliens to engage in war-work have increased, so that the number who now remain unemployed is negligible.

The economic absorption of pre-war refugees has broken down their isolation, removed prejudices and enabled them to become acquainted with the British way of life. By and large, they have proved a valuable element in society: they have made contributions to the national life in industry, in the universities, in the arts and in science, and have acquitted themselves well during the War. The number of those who will wish to remain in Britain is estimated as roughly 40,000 , a figure which is much smaller than in other countries before refugee emigration began in 1933. This number should be absorbed without difficulty after the War : a full employment policy for Great Britain should mean the disappearance of the refugee problem as we knew it before the War; but the refugees must be given a fair chance of sharing both the rights and obligations of British eitizens.

\section{Technological Museum of New South Wales}

The annual report of the curator of the Technological Museum of New South Wales for the year ended December 31, 1942, states that the scientific work of the Museum has been placed on a war footing without necessitating any reorganization of laboratory work. Chemical investigations of national importance have included the recovery of by-products from. charcoal burning, dyeing of khaki cloth, preparation of coloured flashes and composition of flash powders and smoke screens from motor exhausts, fireproofing paper and 'Cellophane' gas respirators, Australian essential oils as mosquito repellents, rot-proofing of sandbags, strength of laminated plastics for aireraft, production of lactic acid and lactates from waste whey, and sources of quinine and similar alkaloids in Australia. Work has also been done on synthetic wax, fire-proofing fabrics for camouflage purposes, synthetic rubber from acetylene, production of drugs and natural dyes from Australian plants, camouflage materials, especially paint, wax from sugar-cane, and the relative humidity for controlling the development of moulds likely to attack silk parachutes in Queensland. Botanical investigations into the cultivation of the tung oil tree in Australia, as well as on suitable Australian fibres to relieve the shortage of imported material, and the important research on the cytology of the eucalypts and other genera, were continued. Much time has been devoted to the study of rot-proofing problems in the preservation of jute hessian, canvas and manilla, hemp and cotton rope and to the waterproofing and rot-proofing of canvas duck. Lists of lectures, etc., delivered, papers read before scientific societies, exhibits and publications are included.

\section{Performance of Generating Plant}

A Papkr read in London on February 3 before the Institution of Electrical Engineers by R. W. Biles and G. W. Maxfield reviews the performance of a group of generating stations over a five-year period, commenting upon coal qualities, thermal efficiency, analysis of the different classes of breakdown with deductions as to probable operating life between breakdowns, plant availability and the effects of loading. The plant under review is divided into three groups: pre-1930, 1930-1937 and 1938-1942. 
From the results, curves for maximum probable availability are deduced. The suggestion is made that 'operating efficiency' should be calculated on a uniform basis and included in station records. The need for an overall standard by which the performance of generating stations can be judged is discussed, and the term 'standard merit', based upon operating efficiency and plant availability, is suggested.

It is concluded from the analysis that pre-1930 plant should not be operated at above 45 per cent average running plant load-factor if good availability is to be consistently maintained; marked improvements are to be noted in availability of the most recent plant installed since 1938 at 80 per cent average running plant load-factor ; the lower breakdown rate per plant item of the pre-1930 group is notable when compared with that of the later plant groups. Good quality and grading of fuel supplies are needed, particularly for the pre-1930 plant, if maximum outputs are to be obtained. With larger units of plant, greater outputs between breakdowns have been possible; but it is not safe to conclude that larger units still would be to the general benefit of the supply industry. Size of unit required is related to the load curves and security needs.

\section{Economic Rating of Motors and Transformers}

IN a paper read by Mr. D. J. Bolton before the Institution of Electrical Engineers on December 2, physical and economic ratings of motors and transformers respectively are compared, and the scope and limits of economic choice are discussed and illustrated. A method of economic selection is proposed through the use of larger standard machines, and a technique is developed for investigating the economy of changes in rating. Tables of data and results are given at the end of the paper, and the methods employed in these tables are explained in some detail. The results are expressed in the form of an 'economic advantage' obtainable through under-running or overrunning, and show the former to be highly advantageous in a large number of cases. Methods of implementing the results are discussed.

\section{Canadian Mortality in War Years}

According to an annotation in the September issue of the Statistical Bulletin, the health of the Canadian people has remained at a very favourable level during the four years of the present War, the mortality in this period being the lowest on record. The improvement in mortality has been particularly marked in the diseases most prevalent among the young. Not only has the death-rate decreased among the communicable diseases of childhood, but also there has been an increased fall in the mortality among the large number of young adults in training camps. Diarrhoea and enteritis, which have always been important causes of death among Canadian children, have also shown considerable improvement in recent years. The rate of decline in tuberculosis is illustrated by a new minimum of $47 \cdot 1$ per 100,000 , which is about one fifth below that for the period 1934-36. In contrast with the catastrophic influenza epidemic towards the close of the War of 1914-18, there has so far been no cause for serious concern, although there was a mild epidemic of influenza in Canada late in 1940 and early the following year, the favourable result being mainly due to the use of serum and chemotherapy in the treatment of pneumonia.
Chemotherapy has also succeeded in reducing the mortality from appondicitis and the diseases incidental to child-bearing. On the other hand, there has been an increase in the mortality from cancer, diabetes, diseases of the heart and arteries, and from accidents.

\section{Announcements}

Prof. A. R. Todn, Sir Samuel Hall professor of chemistry in the University of Manchester, has been appointed professor of organio chemistry in the University of Cambridge.

Prof. Anton J. Carlson, chairman of the Dəpartmont of Physiology in the University of Chicago, has been elected president of the American Association for the Advancement of Science.

TeE title of professor emeritus of bacteriology in the University of London has been conferred on Sir John Ledingham, on his retirement from the professorship of bacteriology at the Lister Institute of Preventive Medicine. The degree of D.Sc. has been conferred on Mr. B. Prasad (University College), Dr. E. C. Barton-Wright (Birkbeck College and Chelsea Polytechnic), Mr. A. G. McDonnell Weddell (St. Bartholomew's Hospital Medical College), and Mr. George King.

The Edison Medal for 1943 of the American Institute of Electrical Engineers, one of the highest honours in the field of electrical science and engineering, has been awarded to Dr. Vannevar Bush, president of the Carnegie Institution of Washington and director of the Office of Scientific Research and Development of the U.S. Office of Emergency Management, "for his contribution to the advancement of electrical engineering, particularly through the development of new applications of mathematics to engineering problems, and for his eminent service to the nation in guiding the war research program". Dr. Bush has also just received the Holly Medal of the American Society of Mechanical Engineers, for his work as a leader of engineering education and in scientific research, and in particular for his work on calculating machines.

OwING to the generosity of the Rockefeller Foundation of New York, which has for the fourth year in succession provided a grant for the purpose, the Royal Society is in a position to give some assistance to scientific societies and associations which, as a result of war conditions, are experiencing financial difficulties in the publication of scientific journals.

The following appointments to the Colonial Service have recently been made: E. Dixon to be veterinary officer, Nigeria; W. J. J. Filkins to be physiological laboratory superintendent, Uganda; J. S. Groome to be forest officer (temporary), Tanganyika; G. W.P. Streeton to be deputy government chemist, Jamaica.

Errata.-We are asked by Dr. A. Hunter to make it clear that the experiments on exposure-time effects in photographic photometry attributed to him in NATURe of February 26, p. 242, were planned and carried out by Prof. W. M. H. Greaves, Astronomer Royal for Scotland. Furthermore, the microphotometers he described at the symposium give intensity traces direct, not merely density records, as stated. 